\title{
Children's rights in a changing climate: a perspective from the United Nations Convention on the Rights of the Child
}

\author{
Susana Sanz-Caballero* \\ Department of Public Law, University CEU Cardenal Herrera, Luis Vives 1, 46115 Alfara, Spain
}

\begin{abstract}
Human rights are seriously affected by climate change, but children and children's human rights are of most concern. The purpose of this article is to show how climate change and the associated phenomena harm children and their rights. The United Nations Covention on the Rights of the Child is the most universally ratified human rights treaty in the world. It is also one of the most complete ones, as it covers both civil and political rights, as well as socio-economic and cultural rights. This research examines the rights enshrined in the United Nations Convention on the Rights of the Child in the light of climate change effects. It identifies which children's rights are most affected by climate change. To do this systematically, the rights of this covenant have been categorized into 4 groups: rights which satisfy basic needs (right to life, right to health, right to water, right to food and right to housing); specific children's rights (right to be cared for by parents, right to education, right to play, and right to leisure and access to culture); participation rights (right to active participation, right to freedom of expression, association and assembly, accountability and right to an effective remedy); and civil and political rights (right to a nationality, right to birth registration and right to preservation of identity, right to equal protection against discrimination, right to privacy and family life and right to property). The article identifies how, which and to what extent rights listed in the covenant are undermined by sudden climate change events, as well as by the gradual consequences of climate change. It shifts the perspective on how we address climate change consequences: from human impacts to real human rights' violations.
\end{abstract}

KEY WORDS: Children's rights - Climate change effects - UN Convention on the Rights of the Child $\cdot$ Global warming $\cdot$ Consequences on vulnerable groups

\section{INTRODUCTION}

At the end of the 1980s and at the beginning of the 1990s climate change was seen as an issue linked to the study of natural sciences. It was a meteorological, geological and an environmental topic. Sometime later, it was also regarded as a problem of energy resources, and it was included in the economic sciences agenda. Long after the problem arose, we discovered that it was also a policy issue and a threat to international peace and security, realizing that it had an irreversible and negative impact on human rights.
Now climate change has become a key subject for social scientists and human rights activists.

What have human rights to do with global warming? The answer to this question is quite simple: if human rights are universal basic guarantees that all human beings are entitled to have, then the consequences of climate change that kill life and damage health, livelihood, means of subsistence and even culture, make the enjoyment of those human rights impossible. There is not a single right whose enjoyment is not directly or indirectly affected by global warming. 
The most vulnerable social groups are also the most sensitive to the effects of climate change. Among them, populations from developing countries, poor people living both in developing and developed States, indigenous people who depend on close contact with the earth to survive, and, of course, the youngest members of society, that is, children.

Climate change has major implications for children, especially when combined with poverty (Barlett 2009, p. 133). Shifts in temperature and precipitation patterns create serious barriers for child survival. Extreme weather conditions undermine all the gains achieved until now in the field of children's rights. According to the United Nations' Development Program (UNDP) and its Human Development Report 2007/2008, climate change is already undermining the achievement of the Millennium Development Goals (MDGs), especially those MDGs which have to do with children, such as the goals of reducing poverty, malnutrition, infant mortality and maternal mortality; the goals of fighting malaria and other diseases, and providing all children access to primary education by 2015 (UNDP 2008, p. 24 to 25 \& 100). Furthermore, not only are all of the MGDs critical for children's lives today, but their achievement is also crucial for the next generations of both children and adults. Millions of lives have been saved by the improvement of access to basic supplies, such as water and sanitary services, health care and nutrition programs. But now all this progress is being hindered because of permanent damage to the environment (Veneman 2007, p. 2, UNICEF 2005b, p. 11). The UN Human Development Report 2009/ 2010 stated that climate change may be the single factor that makes the future very different from the past, impeding the continuation of human progress that history would lead us to expect (UNDP 2010, p. 102).

In Mary Robinson's words, climate change is about human suffering (Robinson 2008, p. iii). The consequences of climate change are sudden, horrific and unexpected manifestations, such as heavy storms, floods, landslides, fires, tornados, cyclones and hurricanes, as well as progressive but imperceptible phenomena, such as desertification, habitat destruction, drought, heat waves, exhaustion of wells, deforestation, species extinction, ice melting, receding coastlines, rise in sea level and ocean acidification. All these cataclysmic and non-cataclysmic phenomena have immense human consequences. If they persist, livelihood and civilization as it is known today will gradually vanish. Global warming is a threat multiplier (Brown 2010, p. 42). It is 'exacerbating existing drivers of conflict and creating new ones' in a way that is rolling back development in many countries (Brown et al. 2007, p. 1143)

Children's rights are no less affected by climate change than those of adults. Children share many of the same rights as adults, but they are entitled to a number of specific rights as well. They are particularly vulnerable and dependent on adults' care. This is the reason why they are also entitled to a number of additional and particular rights that recognize their special need of protection (right to play, to primary education, to be cared for by parents, to be free from hazardous work, and to leisure). Changing climate impacts the children's right to life, health, food or housing, but it also has less visible consequences for children's rights, such as those derived from parents' death or abandonment following extreme climatic events. Children are usually members of a family and community. Therefore, the violation of children's human rights occurs not only because of direct violations of the rights particularly assigned to children, but also because of violations of family rights or violations of the rights of the communities where children live. Climate change raises a myriad of threats for children. Different climatic phenomena have different effects on different human rights that children should enjoy.

The United Nations Convention on the Rights of the Child adopted on November 20 of 1989 (UNGA res. 44/25) is the most universally ratified human rights treaty in the world. It is also the key international legal instrument with which to compare actual children's rights with reality. In the following pages, an analysis and subsequent interpretation will be made of the rights enshrined in the United Nations Convention on the Rights of the Child in the light of the effects of climate change. The novelty of the approach stems from the fact that the United Nations Convention on the Rights of the Child was not meant to protect children from the consequences of climate change. Nevertheless, the research will identify which children's rights are most affected by climate change. This paper is new in that it uses International Human Rights Law to address the consequences of climate change. The argument used is not centered on the idea of 'human impacts' but on the idea of 'human rights violations'. In order to identify which children's rights from the Convention on the Rights of the Child are most affected by climate change in a systematic way, the rights of this ambitious covenant have been categorized into 4 groups: rights which 
satisfy basic needs (right to life, right to health, right to water, right to food and right to housing); specific children's rights (right to be cared for by parents, right to education and rights to play, leisure and access to culture); participation rights (right to active participation, right to freedom of expression, association and assembly, accountability and right to an effective remedy); and civil and political rights (right to nationality, right to birth registration and right to preservation of identity, right to equal protection against discrimination, right to privacy and family life, and right to property). All these children's rights will be confronted with the adverse consequences of climate change. The analysis will focus on how and to what extent climate change erodes children's rights. It will also address the obligations for States stemming from this covenant. This confrontation will show 3 results: first, children are more vulnerable to climate change than other groups of the population. Second, children's rights are severely at risk due to climate change. Third, despite the fact that the responsibility for climate change consequences is difficult to allocate, States have a large share of this responsibility.

\section{SPECIAL IMPACT OF CLIMATE CHANGE ON CHILDREN'S RIGHTS}

Most of the core human rights treaties were concluded before mankind was aware of climate change. Therefore, these international hard law tools do not mention or address the question of human rights abuses provoked by climate change (HREOC 2008, p. 7). These texts were meant for the protection of individuals against State attacks. They were not drafted to remedy human harm provoked by environmental degradation (Epinay 2010, p. 371 \& 379). However, States have the responsibility of taking action and providing a remedy for direct or indirect threats to these rights, including those caused by climate change. States must also preserve human rights.

The United Nations Convention on the Rights of the Child is probably the first universal treaty to include several references to the environment. In its preamble, the convention states that the natural environment deserves protection for the growth and well-being of the members of society, and particularly children. In Article 24, the convention addresses the right to health and health services, as well as information to help children stay healthy. The environment is also mentioned in Article 29, as one of the aims of children's education $\underline{1}$.
Climate change has the bitter effect of demonstrating that all human rights are indivisible, interdependent and interrelated, and that there is no such thing as principal and secondary rights ${ }^{2}$. First, second and third generation rights are equally affected by global warming phenomena. Likewise, the deprivation of one right adversely affects the others. Climate change interferes with all internationally recognized human rights. This is also the case concerning children's rights. The 4 categories of rights that have been extracted from the Convention on the Rights of the Child are similarly affected by the adverse implications of climate change.

\section{Rights which satisfy basic needs}

Climate change affects very basic elements of life. Environmental quality is a condition for the full realization of many rights. The rights that satisfy basic needs emanate from the necessity to survive and to enjoy an adequate standard of living. Among them we could cite the right to life, the right to health,

\footnotetext{
1More recent international documents have expressly addressed the link between human rights and climate change, but most of them have a soft law character. This is the case of the declaration known as 'A world fit for children', adopted by consensus at the UN General Assembly Special session on children of 2002, which articulates very clearly the commitment of States: 'to give every assistance to protect children and minimize the impact of natural disasters and environmental degradation on them' (A/RES/S-27/2, p. 3, Para. 7). In 2008 the Human Rights Council dedicated resolution 7/23 to 'Human rights and climate change'. In it, the Council expresses: 'Concern that climate change poses an immediate and far-reaching threat to people and communities around the world and has implications for the full enjoyment of human rights' (res 7/23, p. 1). At a regional scale, the Organization of American States issued a declaration in 2008 dedicated to the link between climate change and human rights violations where it stated that the realization of many human rights is related to and dependent upon the physical environment (Article 24 of the African Charter on Human and People's Rights and Duties, adopted on June 27, 1981, OUA, CAB/LEG/67/3 Rev. 5 and Article 5 of the Additional Protocol to the American Convention on Human Rights in the Area of Economic, Social and Cultural Rights, adopted on November 17, 1988). Before that, 2 regional hard law instruments, the African Charter and the San Salvador Protocol to the American Convention on Human Rights, had clearly approached the issue of environmental protection and the importance of a healthy environment. ${ }^{2}$ The Committee on the Rights of the Child has also reflected on the interdependence and indivisibility of all human rights in its general comment No. 5 on the General measures of implementation of the Convention on the Rights of the Child (CRC 2003c).
} 
the right to water, the right to food and the right to housing.

The right to life receives specific protection in Article 6 of the Convention on the Rights of the Child. The UN Human Rights Committee (HRC) has warned against the interpretation of the right to life in a restrictive way. Quite the opposite, States are required to take positive measures to reduce infant mortality and epidemics, and to increase life expectancy (HRC 1982). But Article 6 does not only protect the right to life. It also ensures, to the maximum extent possible, the survival and development of the child. As far as the right to survival is concerned, the preparatory work of the Convention on the Rights of the Child clarifies that life and survival are complementary and not mutually exclusive, and that survival includes the decrease of infant mortality. The right to survival carries with it a more positive connotation than the right to life alone. It means the right to have positive measures taken by States in order to extend the life of the child ${ }^{3}$. The Committee on the Rights of the Child (CRC) understands that the right to survival and development must be implemented in a holistic manner 'through the enforcement of all the other provisions of the Convention, including the right to health, adequate nutrition, social security, an adequate standard of living and a healthy and safe environment' (CRC 2006, p. 4).

It has been recognized that the right to life is necessarily linked to and dependent on the physical environment (Christiansen 2010, p. 57). The effect of a changing climate on the right to life of children can be 2-fold: detrimental consequences can be immediate - in the case of unanticipated negative calamities, for example when children drown during heavy floods - or gradual - when children's health deteriorates due to rising temperatures, epidemics, sun exposure, or insufficient safe drinking water, for example. During disasters children normally face a higher risk of mortality compared to adults and, especially, compared to adult men. They find it harder to escape from danger due to their smaller size, lack of physical strength and their inability to care for themselves. Children are more likely to perish. They are also more likely to succumb to malnutrition, injuries, or disease in the aftermath. Mortality associated with global warming largely affects children under the age of 5 (Back \& Cameron 2008, p. 6 $\& 9$ ). The main killers of children (diarrhea, malnutri-

${ }^{3}$ Preparatory work. Convention on the Rights of the Child, Article 6, p. 121. tion and malaria) are extremely sensitive to climatic conditions. The World Health Organization (WHO) estimates that climate change is responsible for millions of deaths each year caused by preventable diseases. An obscene number of these deaths are children's deaths.

Once life is guaranteed, the right to health comes next. Children have the right to the enjoyment of the highest attainable standard of physical and mental health according to Article 24 of the Convention on the Rights of the Child. This provision also stipulates that States must ensure that every child has access to medical care (facilities and services for the treatment of illnesses and recovery). It also stresses the importance of being informed as to how to prevent accidents involving children (MacDonald 2008, p. 213, Toeves 1999, McMichael \& Woodruff 2006, p. 859 ff.; Sheffield \& Landrigan 2011, p. 291 ff.).

According to the Committee on Economic, Social and Cultural Rights (CESCR) in its general comment on the right to the highest attainable standard of health (CESCR 2000, Para. 1), health is a precondition for other human rights. In the case of children, the lack of health interferes with the right to education, the right to play and many other rights. The $\mathrm{CRC}$, in its general comment No. 4 on adolescent health, expressed that States should provide health services that assure availability, accessibility, acceptability and quality (CRC 2003b). Climate change interferes with these 4 requirements. Children may be affected by unhealthy environments in many ways. They may die from environment-related epidemics and illness. Those weakened by disease are more subject to malnutrition and opportunistic infections. Their mental development may also suffer from unhealthy environments. According to the WHO, climate change is contributing to the burden of disease. Climate change is estimated to be responsible for approximately $2.4 \%$ of worldwide diarrhea and $6 \%$ of malaria cases (WHO 2002, p. 72). Children under the age of $5 \mathrm{yr}$ represent $80 \%$ of malaria deaths. Nearly 5000 children die every day from diarrhea alone. One-third of deaths due to malnutrition worldwide occur in children under the age of $5 \mathrm{yr}$.

Factors that play a relevant role in global warming also harm children's health. This is the case with emissions from vehicles and factories, with their adverse effect on air quality. Asthma, the most common chronic disease amongst children, is expected to increase $20 \%$ by 2016 . Allergies are also experiencing a spectacular rise. Heat waves increase the risk of premature cardiovascular disease because the exposure to extreme temperatures triggers changes in 
blood pressure (Basu \& Samet 2002, p. 190). Vectorborne and water-borne diseases will intensify both. The rise in surface temperature increases the prevalence of water-borne diseases such as diarrhea and typhus and mosquito-borne diseases such as malaria and dengue fever (Patz et al. 1996, p. 218). These hazards affect the right to life and the right to health. Children are the major group of victims of these diseases. The lack of development of their immune system and the immaturity of their organs and metabolism makes it easy for bacteria and viruses to attack their bodies. But global warming is not only increasing the prevalence of existing diseases, scientists warn us of the risk of the re-appearance of forgotten and eradicated plagues (Back \& Cameron 2008, p. 16). Climate change is also affecting children's mental stability. Sudden climate change events and the gradual consequences of climate change often produce environmental anxiety, a type of post-traumatic stress. UNICEF has declared that the quality of a child's environment is a key determinant of whether a child survives the first year of life (Back \& Cameron 2008, p. 4). It should be noted that sick, tired, malnourished and traumatized children in today's world undoubtedly means weak, illiterate and undereducated future adults, with deep emotional scars who will be unable to work.

Global warming is also having the effect of making healthcare infrastructures unavailable or scarce. This is a real problem leading, for the first time in centuries, to a decrease in the standard of health, with a shortage of immunization programs and a lack of medicines and surgical instruments (Riedel 2010, p. 363).

Water is indispensable for life and plays a vital role in every function of the human body. The right to water is a pre-condition for survival. It is inextricably linked to the right to life and to the right to health (Riedel 2005, p. 585-606, Riedel 2006, p. 19-36). The Convention on the Rights of the Child calls in Article 24 for adequate clean-drinking water for children as a responsibility of States in order to fight disease and malnutrition. General comment No. 15 of the CESCR clarifies the normative content of this right stating that the human right to water entitles everyone to sufficient, safe, accepted physically accessible and affordable water for personal and domestic uses' (CESCR 2003). But in today's advanced world, more children die from illness due to dirty water than from any other disease. Children under $5 \mathrm{yr}$ are especially at risk since their metabolism is not fully developed. This explains why 1.5 million of them die each year.
Every $15 \mathrm{~s}$ a child dies from diseases associated with water that is unsafe to drink.

The right to water includes at least 2 different uses of this natural element: the first one has to do with the access to enough fresh drinking water for human survival. The second one has to do with the use of water for personal hygiene and for drainage networks. Illness associated with water shortage and poor sanitation includes dehydration, starvation, hepatitis A, cholera, leptospirosis, diarrhea and communicable skin and eye diseases. The Intergovernmental Panel on Climate Change (IPCC) estimates that by 2020, 75 million Africans will be exposed to increased water stress (IPCC 2007, p. 13). The CESCR informs that 1 billion persons lack access to a basic water supply, and several billions do not have access to adequate sanitation, which is the primary cause of water contamination and water-linked diseases (CESCR 2003, Para. 1).

The increasing contamination of water sources, salt-water intrusion, over-pumping of water reserves, inadequate sewer networks and degradation of freshwater threatens the right to access to water for millions of families. As the earth gets warmer, heat waves and limited water supplies will make access to drinking water and sanitation more difficult. When poor countries suffer drought, its consequences are severe: dehydration, dying cattle, fruitless fields, skeletal children, disease spread and empty classrooms. During natural disasters and emergency situations, States have an additional obligation to preserve and protect the elements that are indispensable for the survival of the population, including drinking water. To fulfill this obligation States are also required to ensure that water services are affordable for everyone, especially for the weakest groups.

The CESCR has addressed the specific circumstances of children with regard to water by stating that 'Governments should take steps to ensure that children are not prevented from enjoying their human rights due to the lack of adequate water in educational institutions and households or through the burden of collecting water. Provision of adequate water to educational institutions currently without adequate drinking water should be addressed as a matter of urgency' (CESCR 2003).

One of the reasons why parents could decide not to send children to school is the lack of water in the school. Another reason could be the lack of separate latrines for boys and girls or even no latrines at all. As the effects of climate change worsen-especially drought and desertification - many schools may run 
out of water completely. Adaptation and mitigation strategies will be needed in order to guarantee the right to education of children.

In the context of children's health, Articles 24 and 27 of the Convention on the Rights of the Child speak about the children's right to food, when addressing the issue that parents have to provide an adequate standard of living for their sons and daughters (Ziegler 2003, 2005, 2008, Golay 2006, p. 117-149). The right to sufficient and good quality food is indivisibly linked to the inherent dignity of the child. According to the UNDP Human Development Report 2006, 600 million people face malnutrition due to climate change (UNDP 2007), especially children.

Sometimes starvation provoked by climate change has its roots not in the lack of food, but in the lack of access to available food, when the price of food rises in the aftermath of catastrophies and ordinary people cannot afford to buy it. In some world regions climate change is leading to the decline in food production. Chronic droughts, floods, rising sea level and diversion of grains for bio-fuel production are diminishing food production. Increased temperatures and changes in rainfall patterns produce desertification and land erosion. As a result, land becomes infertile and livestock die. The rise in sea level causes fish migration. Hunting will be more and more difficult due to species extinction. Climate change has an adverse effect on food security by reducing the availability of food, worsening the stability of the food supply and its price and affecting its utilization. As an example, in Kenya, children under 5 yr are $50 \%$ more likely to suffer malnutrition if they are born during a drought. The relation between malnutrition and disease is bi-directional, because underweight children are more likely to suffer all kinds of diseases.

As far as the right to housing is concerned, the Human Rights Council has expressed its view that the right to housing is correlated to the right to an adequate standard of living (Human Rights Council 2008). In the Convention on the Rights of the Child the right to adequate housing is enshrined within the right to an adequate standard of living, together with the right to nutrition and clothing in Article 27. The CESCR has defined the right to housing as the right to live somewhere in security, peace and dignity. It has also expressed its view that the expression 'adequate housing' is determined partly by social, economic, cultural, climatic, ecological and other factors. It has also identified some aspects of this right that determine the adequacy of housing. These aspects are the legal security of tenure, the availability and affordability of materials, facilities and infrastructures, the habitability, the accessibility, the location and the cultural adequacy (CESCR 1991, Para. 8).

Climate change undermines all these aspects of the right to housing alike, and families and children suffer from it. There is a vicious circle between climatic phenomena, precarious access to natural resources, poor physical infrastructure and weak housing (ICHRP 2008, p. 1). Millions of children are forced to migrate, forced to live in precarious homes, or forced into homelessness due to climate change affecting their dwellings. They experience the drama of the destruction or the loss of their houses and of all their belongings, the rising price of both rentals and new lands, the inability to inherit their parents' possessions, the need to build new dwellings in polluted or dangerous sites, or unsafe conditions of habitability. Growing numbers of families in search of a better life are pushed and will be pushed to migrate to urban centers. The newly arrived often end up settling in locations lacking security of tenure, basic services and sanitation. Families suffer difficulties in acceding to private housing because of xenophobia, unemployment, uncertainty about their income, or lack of legal documents. They live in overcrowded, unplanned, segregated, unhealthy substandard settlements. Undocumented migrants try to remain invisible to authorities. They live under the threat of eviction and perpetuate the vicious circle of marginalization and abuse. Precarious and weak shelters, built in hazardous areas, face the risk of flooding, landslides and other tragedies. These disgraces could force families to move to new settlements in slum areas of megacities or in marginalized rural towns. Children living in these ghettoized areas risk becoming victims of human trafficking and slaverylike conditions, since climatic catastrophies always produce an increase in the trafficking of children, slavery, sexual violence and labor exploitation.

Governments are contributing to human rights abuses caused by climate change catastrophies if they do not enact disaster planning laws, or when they do not engage in the construction of more resilient housing or when they do not fulfill their role as sensible urban planners. Ensuring that homes are resistant to extreme weather conditions simply protects the right to life (HREOC 2008, p. 14). States contribute to the perpetuation of human rights abuses when they do not assist ecologically forced migrants to obtain personal documentation or to have affordable access to adequate housing. Today, an estimated 1 billion people live in urban slums on fragile hillsides or flood prone riverbanks ${ }^{\underline{4}}$. 


\section{Specific children's rights}

Some of the human rights enjoyed by children are specific to them, although some of these particular children's rights could also be classified as socio-economic rights or as civil rights. Among these are the right to be cared for by their parents, the right to education and the rights to play, leisure and culture.

The child's right to know and be cared for by his/her parents is set forth in Article 7 of the Convention on the Rights of the Child. Climate change is one of the reasons for the increasing number of children deprived of a family environment. When habitats become unsustainable, parents have to travel to earn their living abroad. As parents perish during natural disasters or in the aftermath thereof, the chance for sons and daughters to be cared by their parents vanishes. Sometimes parents die from these events, or they migrate with the intention of working abroad and sending money to the family. Sometimes they just abandon or sell their children when they feel the future to be hopeless. The children left behind risk falling into the hands of gangs and organizations that traffic human beings. There are growing numbers of child-headed households, children put in alternative care and street children due to global warming impacts.

The right to education can be classified as an economic right, a social right and a cultural right. It is also, in many ways, a civil and political right as well, since it is central to the full realization of these types of rights (CESCR 1999a, Para. 2, CESCR 1999b, Para. $1 \& 2$ ). Education is for climate change as important as health. Well-educated children are better prepared to recognize threats. Climate change affects the right to education in at least 2 ways: first, when children are forced to flee, alone or with their families, due to uninhabitable conditions, education may

\footnotetext{
4The melting or collapse of ice sheets alone threatens the homes of 1 in every 20 people (UNHCHR 2009, Para. 13). To give some examples, the rising of the sea level on the Ivory Coast in 2011 destroyed hundreds of homes. Thousands of families lost their houses in the capital, Abiyan. Meanwhile, Mauritania has suffered biblical floods and some estimate that $80 \%$ of the capital city of Nouakchott will be under the sea by 2020. The same menace applies to most countries in the Guinea Gulf (Periodistas-es, El mar amenaza a África occidental, 3 October 2011). Tuvalu is suffering irreversible damage due to rising sea level, the subsequent consequence being loss of homes and lifestyles. Thailand tried in 2012 to save its capital Bangkok from severe flooding; homelessness was the result for countless families and orphaned or displaced children.
}

be interrupted until it can be continued in their new settlement. Second, for those who stay, education may become impossible.

According to Article 29 of the Convention on the Rights of the Child, some of the aims of education are to promote, support and protect an enhanced sense of identity and affiliation of the child, his or her socialization and his or her interaction with the environment. Education must be provided in a way that reinforces specific values, such as respect for the children's cultural identity and respect for the natural environment. As far as the cultural identity is concerned, climate change may have the effect of eroding lands, lifestyles and cultures. Respect for the natural environment should be learned by children in a way that encompasses both national and international problems such as global warming and in a way that actively involves children in local, regional and global environmental projects. In situations of natural calamity, war and instability, the educational system should promote mutual understanding, peace and tolerance (CRC 2001, Para. 13 \& 16).

UNICEF warns that a decline in a child's access to education is closely linked to breakdowns in family, social and economic structures. One very common reason for school non-attendance is the deterioration of a child's health and nutritional status - a hungry child is not able to follow any lessons at all. Another reason has to do with the potential financial problems of families who cannot afford school fees, stationery, or school books. Other reasons for school non-attendance are the employment of children in such tasks as fetching water, herding cattle and collecting firewood; the lack of latrines at school; or the lack of separate sanitation facilities for girls (Back \& Cameron 2008, p. 20); family-induced child labor in order to supplement household income; street children who are not cared for by either their extended family or institutions; the destruction of schools or school materials; the departure of teachers due to global warming risks; the unaffordability of reconstruction and relocation costs for new schools; migration to new areas where families are left undocumented; and xenophobia and social exclusion for newcomers.

Children enjoy the right to rest and leisure, to engage in recreational activities and to participate in cultural life and the arts, according to Article 31 of the Convention on the Rights of the Child. Unfortunately, climate change negatively affects all these rights. As a result of climate change, children often have to work to help increase the family income, missing their chances to play. Sometimes they fall 
into the hands of sexual or labor exploitation networks, where they lose their childhood and their opportunities for leisure and play. Climate change also prevents millions of children from enjoying their leisure time because, as a result of desertification, drought, or floods, they have to walk for hours to fetch clean water for the household or look after the cattle. These children spend their time away from home, from recreational and cultural activities and from their friends. At the same time, climate change destroys public recreational infrastructures in parks, gardens and schools. When a family's home is destroyed, children also lose many precious possessions, including toys and school supplies.

\section{Participation rights}

Participation or procedural human rights are equally affected by climate change, but they are not mentioned very often in the context of environmental damage (Pallemaerts 2004, p. 14 ff.). They have to do with the idea of giving voice and process to climate change victims. This is why they are also called 'empowerment rights'. Article 6 of the UN Framework Convention on Climate Change of May 9, 1992 includes the principles for the participation of concerned citizens: transparent and ready access to information concerning the environment is to be provided by public authorities; the right to participate in decision-making processes, the need to encourage public awareness and the right to effective access to administrative and judicial proceedings, including redress and remedy. By focusing on children as rightholders, States are responsible for providing for their participation, supplying relevant information and allowing consultation.

In this section, we will analyze the freedom of information, the right to active participation, the freedom of expression, association and assembly, and the right to an effective legal remedy. The Convention on the Rights of the Child grants some participation rights to children. Article 13 of the Convention grants children the right to freedom of expression, and it states that this right shall include the freedom to seek to be informed and to express ideas. Article 17 also recognizes the importance of the mass media and ensures that the child has access to information from a variety of sources, especially those aimed at the promotion of his or her well-being and health.

Access to information is a critical component of the fight against climate change, especially for children. States must promote and facilitate the flow of infor- mation, because well-informed citizens and wellinformed children can cope better with the harmful consequences of climate change and can better address their risks. Well-informed children will be careful with sun exposure, they will learn basic lessons about how to behave in emergency situations or how to purify well water. There is a duty for States to disseminate information on climate change in a language and also by means that children can access and understand (Amnesty International 2009). Children have the right to be informed accurately about the origins of climate change and its symptoms, risks and consequences. Otherwise, they will not be able to adapt themselves. Information on how to handle and survive climate change is necessary for children, but it is very seldom provided at school. This is as important as providing health care. A well-informed child is better prepared to recognize in advance the threats posed by a changing climate (Christiansen 2010 , p. 27). Most of the time, information about climate change is not only inaccurate but deliberately confusing or vague. Some authors even suggest the risk of censorship (Lador 2004, p. 9). This is because the information, data and statistics on the effects of climate change or on emissions are sometimes provided by the same actors (be it States, companies, industries or others) whose activities provoke climate change. This is a problem in connection with the right of adults and children to be informed. Noteworthy is the fact that information is also more detailed in rich areas that experience lesser impacts, but less detailed in the areas that suffer the most devastating consequences of climate change. The right to information is linked to the affected people's right to active participation and consultation in the decision-making process regarding the policies that are going to shape their lives. According to Article 12 of the Convention on the Rights of the Child, children are entitled to express their own views freely in all matters affecting them. Due weight should be given to these views in accordance with the child's age and maturity. This article also means that children should have the opportunity to be heard in judicial and administrative procedures affecting them. Children are right-holders and governments have obligations on their behalf. One of them is to make channels available for them to be informed and to participate in climate change mitigation, adaptation and relocation policies.

In July 2009, the Committee on the Rights of the Child adopted its general comment No. 12 on the effective implementation of Article 12 providing strong justification for children's participation in cli- 
mate change decisions. In the Committee's words: 'If the best interests of a large number of children are at stake, heads of institutions, authorities, or governmental bodies should also provide opportunities to hear the concerned children from such undefined groups and to give their views due weight when they plan actions, including legislative decisions, which directly or indirectly affect children' (CRC 2009, Para. 73).

Children have the right to participate, according to their maturity, in climate change talks, programs and decisions. They are the next generation of water users and environmental guardians of households and communities. Although they are victims of global warming, they should not be treated as mere victims, but as active participants (Back \& Cameron 2008, p. 2). Child participation is both a process and a goal. Children need to have a say in the most important decisions that will affect their future (Walden et al. 2009 , p. 3). States must ensure full participation of representatives of vulnerable groups in the design of adaptation and mitigation strategies. Environmentally aware children are important agents of change for the long-term protection of the earth. They are enthusiastic and engaged as few adults can be. Besides, they are more concerned about the future of the environment. In the course of climate change talks, children's opinion should obviously be taken into account according to their age. Children's participation in topics such as water, sanitary services, soil degradation, polluting agents and emissions can provide a unique means of introducing healthy practices among both families and communities (UNICEF $2005 a$, p. 6, UNICEF 2005b, p. 47). However, this is hardly the case. Children's participation is not the rule at all (CONAGUA 2006, p. 10). They are normally ostracized from decision-making processes and deliberations on how to reverse climate change. This is a very challenging issue, one that faces obstacles such as cultural traditions on the role and place that children have to play in society. Adults have to value children's opinions according to their age. Children can help adults to challenge the status quo. But this is not only an opportunity we adults have to give them: it is more than that; it is their right. If we do not allow them to participate, we are ignoring their human rights.

There are some other participation or procedural rights within the Convention that are strongly linked to the idea of children having a say in climate change talks, negotiations, decision-making and protest actions, i.e. the right to peaceful assembly and the right of association as per Article 15 (HRC 2011). The right to peaceful assembly, even if it is against government action or inaction with regards to climate change, is a crucial safeguard that must be protected. The CRC is of the opinion that children's views are rarely taken into account and access to organizations that may protect their rights is generally limited. Children's concerns in environmental matters and children's participation in environmental organizations are not an exception to this reality (CRC 2002, Para. 5).

For rights to have meaning, effective legal remedies must be available to redress violations (CRC 2003b, Para. 24). However, human rights lawyers are aware of the difficulty of assigning liability to public and private actors for climate change related harms. When the actions or omissions of States result in human rights violations or abuses, victims should have access to an effective remedy. If the human rights violation has its origins in climate change impacts, States are also accountable for that. If the victims of the human rights violations are children, they should also have access to an effective remedy. Government, on the whole and at all levels, is obligated to promote and respect the rights of children.

As the effects of climate change increase, litigation is likely to increase as well. However, one of the trickiest problems of climate change litigation is how to allocate responsibility for human-induced climate change and its harmful consequences ${ }^{5}$. It is difficult for any victim of climate change harms to have access to justice. Yet, children are confronted with an added and almost insurmountable difficulty, their age. If they are not helped by adults, children will normally lack the information, the knowledge, the ability, and the capacity to persuade, as well as the economic resources to identify and activate the few 'effective' remedies available for climate change damages to which they are victims. To sum up: climate change provides clear evidence of the inadequacies of the international justice system in the face of changing threats and new and unexplored patterns of responsibility.

\section{Civil and political rights of children}

Some of the rights previously addressed as specific children's rights or participation rights could also be considered as civil and political rights. As they have been analyzed before, we will concentrate now on the rights to a nationality, to birth registration and to the preservation of identity, the right to equal protection against discrimination, the right to privacy and family life, and the right to property. 
Article 7 of the Convention on the Rights of the Child provides for the right of the child to be registered immediately after birth, the right to a name from birth and the right to acquire a nationality. Article 8 establishes the obligation for States to preserve the child's identity, including nationality, name and family relations as recognized by law without unlawful interference.

Unexpected climate disasters could separate children from their parents. Many children may become orphans or lose any trace of their parents forever. In these situations, birth registration is critical to ensuring children's rights. Domestic law must ensure that property and inheritance rights of orphans are duly preserved. When confronted with forced migration due to global warming phenomena, parents' personal documentation may get lost or left behind. They may enter another country without a visa or without the authorities' permission, and they may fear eviction and expulsion. In these circumstances, newborns from these parents may not be registered after birth. The right of the child to acquire a nationality is also at

\footnotetext{
$\underline{5}$ There are several reasons for this litigation obstacle. (1) Responsibility for impacts may not be assigned to the government nearest to the victim, but may also be attributed to far away countries. Extraterritorial responsibility is hard to establish. (2) States are not the only ones to be blamed, but also public and private entities. However, the international responsibility and scrutiny of the latter are more difficult to determine, especially when many of the greatest emitters do not operate in one State. Corporations have not been recognized as subjects of International Law. (3) The harms caused by climate change can be attributed only indirectly to the identified perpetrators. The nature of global warming makes it impossible to establish a direct causal link between a specific past emission and a specific harm to a specific person. (4) The rights concerned are sometimes difficult to enforce (migrants rights, rights in time of war), and the harms are yet to come. (5) Courts are not likely to accept cases where harms are not very concrete (human rights litigation ordinarily works by addressing specific injuries caused by specific perpetrators and experienced by specific victims, who must have standing to bring the case before a competent court). (6) Human rights prioritize harms to actual persons, not to future generations, whereas responses to climate change must reflect the rights of children, including those to be born. The rights of future generations are at stake due to climate change, but there are strong arguments against entitlements and litigation in the name of people not yet born. (7) Emergency conditions - as in cases of famine, floods, mass migration, for example-limit the application of human rights law. Governments are very likely to take measures abdicating their human rights obligations in the aftermath of climate disasters. Some of these handicaps for environmental litigation are explained in International Council on Human Rights Policy (ICHRP 2008, p. 4 and 45) and UNICEF (2011, p. 3).
}

stake. This right may also be at risk when a country is swallowed up by the sea, as in the case of small islands where families have already fled to from other countries. Children may find themselves in the unprecedented situation of being citizens of a State that no longer exists. If the recipient State does not provide its own nationality for the sons and daughters of eco-migrants, those children may become stateless. As stated by the UN High Commissioner on Human Rights, the disappearance of a State for climatechange-related reasons gives rise to a range of legal questions, including the status of the inhabitants of such disappearing territories. International Law does not provide clear answers (Wagle 2008).

As far as the right to equal protection against discrimination is concerned, the non-discrimination clause of Article 2 of the Convention on the Rights of the Child requires States to identify children and groups of children for which the enjoyment of their rights may demand special measures. In this group of especially vulnerable children, we can undoubtedly include those more severely affected by global warming. Children are entitled to equal protection under the law without discrimination. However, as they are more at risk, they are entitled to additional protection compared to adults. However, the reverse is the rule: the existing social inequalities that jeopardize children's rights are exacerbated by global warming.

According to the High Commissioner on Human Rights, irrespective of the limitation of resources, States must guarantee non-discrimination in the access to human rights (UNHCHR 2009, Para. 25). The High Commissioner speaks about a 'climate injustice' because the consequences of climate change fall unequally, particularly upon those who are the least capable of bearing its weight. Climate change is not only related to environmental factors, but also to poverty, discrimination and inequalities ${ }^{6}$. The need to combat inequality and discrimination brings into focus how climate change affects people differently. Climate change exacerbates existing inequalities and vulnerabilities, which are consequences of factors such as discrimination regarding health status, access to knowledge and access to information. There is a need to advance adaptation and mitigation measures in an effort to enable everyone to live in dignity (Ize-Charrin 2008) ${ }^{7}$.

\footnotetext{
${ }^{6}$ Opening remarks in the Human Rights Council panel discussion on the relationship between climate change and human rights, June 15, 2009.
} 
Children affected by global warming and natural disasters may encounter problems like unequal access to assistance, gender-based discrimination and violence or discrimination in the supply of aid. Furthermore, environmental destruction can result in discrimination and racism (Perrez 2004, p. 5). A side effect of climatic events is the intensification of existing gender inequalities, as girls are more likely than boys to stay out of school in order to work at home and fetch water and wood from far distances. In some countries, they are less likely to be visited by a doctor and to have access to health services. Post-disaster reconstruction should prevent discrimination based on gender and on racial or ethnic grounds. Postdisaster reconstruction should also make sure that the rights of children are adequately addressed. Girls generally suffer the worst burden of the existing traditional gender roles, as the responsibility for securing food, water and energy normally lies with them. Certain effects of climate change like drought and changing rain patterns can result in increased discrimination against them in their access to schools and their rights to play and leisure time.

Although the objective of the rights to privacy, home and family life of Article 16 of the Convention on the Rights of the Child is essentially that of protecting children from arbitrary interferences from public authorities, it may also imply in certain circumstances the positive obligation of States to adopt measures designed to secure the rights enshrined in this article. At a regional level, the European Court of Human Rights (ECHR) has recognized that the right to family life can be violated because of environmental harms that are so severe that they hinder family life (Loucaides 2004, p. 249 ff., Sands 2004, p. 24, Merino 2006, p. 55 ff., Sanz-Caballero 2006, Council of Europe 2009, p. 14). Exemplary for this line of rulings was the case of López Ostra versus Spain (ECHR 1994), about a Spanish family whose life was destroyed due to the construction of a waste-treatment plant close to their home. The disgusting smells and continuous noise produced by the plant prevented the family from carrying on with their previous family life and family organization, forcing them to move to another neighborhood and leading to the mother's severe depression. Although the waste-treatment plant was privately owned, the ECHR determined that Spain had violated Article 8 of the European

${ }^{7}$ Address of the UN Deputy Right Commissioner for human rights at the 7th Gathering for Human Rights, September 28, 2009.
Convention on Human Rights on the right to family life. The Court ruled that the State's obligations do not only apply in cases where the harm is directly caused by State activities, but also when its origin lies in the private sector because the State has the obligation to guarantee that human rights are implemented within their jurisdiction.

The inviolability of the home can also be at risk in the aftermath of catastrophic events, when families have to flee or are unable to reach their homes, and all their belongings are left behind. Therefore, the right to property is one of the rights affected as a consequence of climate change. Climate change may also result in the loss of property without compensation, particularly along the coast and on small islands where the sea level is gradually rising (Human Rights Council 2011). If this is the case, there is a need to assure property restitution in the case of temporary flight. Although land property is not normally a child's business, the deprivation of property will affect the child's right to inherit his or her parents' possessions. Protection of the right to enjoy one's possessions may require public authorities to ensure certain environmental standards.

\section{CONCLUSIONS}

It is not difficult to agree that global warming is undermining the fulfillment of a wide range of human rights (Picolotti 2008, p. VI). Climate change threatens our life, health, family life, safety and environment. The accelerating deterioration of the environment has its most profound effect on children. The life and personal integrity of our children depend on protection of the environment. There is an intrinsic link between environmental impacts and the fulfillment of human rights. Yet, how global warming is affecting children's rights is a question that is not receiving the attention it deserves.

The 2000 UN Millennium Development Goals appeared to be achievable not very long ago. But today, after the world financial collapse and the worsening effects of climate change, they seem less attainable. The global economic crisis has the side effect of lowering the priority of debate about climate change on the international agenda. Children die, become orphans and homeless, are abducted or deprived of education and health care, and are left with deep emotional trauma. Impoverished children from developing countries have 3 reasons to be more affected by climate change than wealthy adults from developed countries: (1) they are children, (2) they 
are poor and (3) their countries cannot afford any measures to combat climate change.

Childhood is in itself a right and it has to be protected. Almost any environmentally friendly action improves the basic needs of children. Protecting the environment and securing children's well-being are mutually reinforcing goals. What is good for children (providing education, sanitary services, health care, and protecting water supplies and biodiversity) is also good for the environment. Climate change threatens the basic elements of life by being a detriment to health, and limiting access to water, food and land. Climate change is one of the most serious threats for the fulfillment of human rights today. As some authors have expressed, we may be facing the fifth horseman of the Apocalypse (Brown et al. 2007, p. 1153). Regardless of whether the international community manages to set up an ambitious mitigation plan soon, something that does not seem very likely to happen in view of the results of the Durban Conference (COP17/ CMP17 2001), we will suffer the consequences of some climate changes with dramatic effects because of past emissions. Responsibility for the detriments of climate change is not easy to allocate. The physical impacts of global warming cannot easily be classified as violations of human rights, because they cannot easily be attributed to acts or omissions of one specific State. Nonetheless, addressing the harm remains a critical human rights concern and an obligation for States under International Law.

Human rights principles show that governmental obligations do not stop at the border. While States are parties to human rights covenants and are ultimately accountable for compliance, other actors from the private business sector have great responsibilities for the effect of green-house emissions. States have a special responsibility to monitor and regulate private companies, including those operating overseas. States are aware of how climate change threatens human rights. They are also aware that State inaction worsens the situation. They have the duty to avoid any behavior that could be considered a human rights violation or abuse. They have to prevent others from harming the environment (obligation to protect). They also have an obligation to protect individuals against the threats and harms to human rights caused by climate change (obligation to fulfill). States have to use all their means to prevent and address the consequences of climate change and to provide access to remedies in case of abuse. All things considered: States have the primary duty, not only to respect human rights, but to protect and fulfill these rights through positive action ${ }^{\underline{8}}$. Climate change should start being seen through a 'human rights violations' lens instead as through a mere 'human impacts' lens.

Climate change shows how badly we are prepared to fight certain harms to humankind. Among these weaknesses we should include our own human rights protection system, which is supposed to be enforced by the State. Yet, regarding climate change, States are not the only ones to be blamed. Only the improvement and advancement of International Law could change this situation, as the current mechanisms established for the protection of international human rights - including those of the Convention on the Rights of the Child - do not address these kinds of challenges. Despite this weak protection, climatechange-related human rights exist under International Law (Cameron 2011, p. 2). Climate change has become an ethical issue, and we have to face it as such. But it also has to be addressed as a legal issue. It is unfair to leave children a world without the States of Kiribati or Nauru, without many other islands, or without polar bears. A factor contributing to climate change, i.e. humanity's unsustainable way of life, is the adults' failure to take into consideration the rights and needs of the following generations. Humankind is losing its ability to support life. This reduced capacity will trigger armed conflicts over scarce resources ${ }^{9}$. The most vulnerable are the first to

\footnotetext{
${ }^{8}$ The Committee on the Rights of the Child has had the occasion to deal with States' responsibilities regarding the effects of climate change in its Concluding Observations on South Africa, Jordan and Ecuador. In the first case, the Committee expressed its concern about environmental degradation in the country, especially air pollution. In the second case, the Committee recommended Jordan to take appropriate measures-including through international cooperation - to prevent and combat the damaging effects of environmental pollution. In the third case, the Committee noted the negative impact the climatic phenomenon called 'el Niño', as a sub-consequence of climate change, had on the most vulnerable sectors of population, and, especially, children. Article 24 of the Convention on the Rights of the Child urges States to cooperate. In the light of this provision, the Committee on the Rights of the Child recommended Ecuador to seek international cooperation to combat and prevent the damaging effects of environmental degradation. The Committee has shown concern about the high risk for Ecuador's children originating in oil exploitations in the Amazonia region (CRC 1998, Para. 9, 2000a, Para. 50, 2000b, Para. 29).

${ }^{9}$ The United Nations Environment Program suggested in 2007 that the Sudan conflict in Darfur began as an ecological crisis and was partly due to climate change, as a result of tension between farmers and herders over disappearing lands (UNEP Sudan 2007).
} 
suffer the consequences of climate change. This is a mankind survival issue. If we do not succeed, we will have the blame of being the ones who left behind a world unable to support life.

Acknowledgements. This article was written within the framework of the research project DER2009-13752-C03-02 of the Spanish Ministry of Science and Innovation.

\section{LITERATURE CITED}

\section{Resolutions of international bodies and NGO reports}

Amnesty International (2009) Upholding human rights while confronting climate change, September 29, 2009. Amnesty International, London

CESCR (Committee on Economic, Social and Cultural Rights) (1991) General comment No. 4: the right to adequate housing, December 12, 1991, United Nations, Geneva

CESCR (Committee on Economic, Social and Cultural Rights) (1999a) General comment No. 11: plans for action for primary education, May 10, 1999. E/C.12/1999/4, United Nations, Geneva

CESCR (Committee on Economic, Social and Cultural Rights) (1999b) General comment No. 13: the right to education, December 8, 1999. E/C.12/1999/10, United Nations, Geneva

CESCR (Committee on Economic, Social and Cultural Rights) (2000) General comment No. 14 on the right to the highest attainable standard of health, August 11, 2000. E/C.12/2000/4, United Nations, Geneva

CESCR (Committee on Economic, Social and Cultural Rights) (2003) General comment No. 15 on the right to water, January 20, 2003. C/C.12/2002/11, United Nations, Geneva

CONAGUA (Instituto Mexicano de Tecnología del Agua) (2006) Children, water and education. 4th World Water Forum, 2006, Mexico City

COP17/CMP17 (2001) UN climate change conference 2001, Durban (South Africa). Available at: www.cop17_cmp7 durban.com

Council of Europe (2009) Fourth meeting of the group of experts on biodiversity and climate change: human rights and climate change, Strasbourg, April 8, 2009. T-PVS/Inf (2009) 4, Council of Europe, Strasbourg

CRC (Committee on the Rights of the Child) (1998) Concluding observations: Ecuador, October 26, 1998. CEC/C/15/ Add. 93, United Nations, Geneva

CRC (Committee on the Rights of the Child) (2000a) Concluding observations: Jordan, 2000. CRC/C/15/Add. 125, United Nations, Geneva

CRC (Committee on the Rights of the Child) (2000b) Concluding observations: South Africa, February 23, 2000. CRC/C/15/Add. 122, United Nations, Geneva

CRC (Committee on the Rights of the Child) (2001) General comment No. 1 on Article 29: the aims of education, April 17, 2001. CRC/GC/2001/1, United Nations, Geneva

CRC (Committee on the Rights of the Child) (2002) General comment No. 2 on the role of independent national human rights institutions in the promotion and protection of the rights of the child, November 15, 2002. CRC/GC/ 2002/2, United Nations, Geneva
CRC (Committee on the Rights of the Child) (2003a) General comment No. 4 on adolescent health and development in the context of the Convention on the Rights of the Child, July 1, 2003. CRC/GC/2003/4, United Nations, Geneva

CRC (Committee on the Rights of the Child) (2003b) General comment No. 5 on the general measures of implementation of the Convention on the Rights of the Child (Arts. 4, 42 and 44, Para. 6), of November 27, 2003. CRC/GC/ 2003/5, United Nations, Geneva

CRC (Committee on the Rights of the Child) (2006) General comment No. 7, implementing rights in early childhood, September 20, 2006. CRC/C/GC/7/Rev. 1, United Nations, Geneva

CRC (Committee on the Rights of the Child) (2009) General comment No. 12 on the right to be heard, July 20, 2009. CRC/C/GC/12, United Nations, Geneva

ECHR (European Court of Human Rights) (1994) Case López Ostra v. Spain, Application No. 16798/90, December 9, 1994. Council of Europe, Strasbourg

HRC (UN Human Rights Committee) (1982) General comment No. 6, right to life. HRI/Gen/1/Rev. 7, Para. 128, United Nations, New York, NY

HRC (UN Human Rights Committee) (2011) General comment No. 34 on the freedoms of opinion and expression, September 12, 2011. CCPR/C/GC/34, United Nations, New York, NY

HREOC (Human Rights and Equality Opportunity Commission) Commission (2008) Background paper: human rights and climate change. Everyone, everywhere, everyday. Australian Human Rights Commission, HREOC, Sydney

ICHRP (International Council on Human Rights Policy) (2008) Climate change and human rights. A rough guide. ICHRP, Geneva

IPCC (Intergovernmental Panel on Climate Change) (2007) Summary for policymakers. In: Parry ML, Canziani OF, Palutikof JP, van der Linden PJ, Hanson CE (eds) Climate channge 2007: Impacts, adaptation and vulnerability. Contribution of Working Group II to the Fourth Assessment Report of the IPCC, New York, NY

UNDP (UN Development Program) (2007) Human Development Report 2006. Beyond scarcity: power, poverty and global water crisis. United Nations, New York, NY

UNDP (UN Development Program) (2008) Human Development Report 2007/2008. Fighting climate change: human solidarity in a divided world. United Nations, New York, NY

UNDP (UN Development Program) (2010) Human Development Report 2009/2010. The real wealth of nations: pathway to human development. United Nations, New York, NY

UNEP (United Nations Environment Program) Sudan (2007) Post-conflict environmental assessment. United Nations, Nairobi

UNHCHR (UN High Commissioner on Human Rights) (2009) Annual report of the United Nations High Commissioner on human rights, January 15, 2009. A/HRC/10/ 61, United Nations, New York, NY

UN Human Rights Council (2008) Resolution 7/23 on human rights and climate change, March 28, 2008. United Nations, Geneva

UN Human Rights Council (2011) Summary deliberations on climate change and displacement, April 2011. United Nations, Geneva

UNICEF (United Nations Children's Fund) (2005a) Water, sanitation and hygiene education. Children and adoles- 
cents leading the way in Tajikistan. UNICEF, New York, NY

UNICEF (United Nations Children's Fund) (2005b) Water, sanitation and hygiene education for schools. Roundtable meeting, January 24 to 26, 2005. UNICEF UK, Oxford

UNICEF (United Nations Children's Fund) (2011) A brighter tomorrow: climate change, child rights and intergenerational justice. UNICEF UK, London

WHO (World Health Organization) (2002) World health report 2002: reducing risks, promoting healthy life. WHO, Geneva

\section{Doctrine}

Back E, Cameron C (2008) Climate change report: our climate, our children, our responsibility. The implications of climate change for the world's children. UNICEF UK, London

Barlett S (2009) Children in the context of climate change: a large and vulnerable population. In: Guzmán JM et al. Population dynamics and climate change, Vol 80. IIED, London, p 133-148

Basu R, Samet J (2002) Relation between elevated ambient temperature and mortality: a review of the epidemiologic evidence. Epidemiologic Rev 24:190-192

Brown O (2010) Campaigning rhetoric or bleak reality? Just how serious a security challenge climate change is for Africa? In: Climate change resources migration securing Africa in an uncertain climate. Heinrich Böll Stittung, Cape Town, p 38-59

Brown O, Hammill A, McLeman R (2007) Climate change as the 'new' security threat: implications for Africa. International affairs 83:1141-1154

Cameron E (2011) Development, climate change and human rights. From the margins to the mainstream? Social development working paper No. 123, World Bank, Washington, DC

Christiansen SM (2010) Environmental refugees. A legal perspective. Wolf Legal Publishers, Berlin

Epinay A (2010) Refugiés écologiques et Droit International. In: Tomuschat C (ed) The right to life. Martinus Nijhoff, Leiden, p 371-379

Golay C (2006) The right to food and access to justice: the ICESCR before national jurisdictions. In: Borgui $M$, Postiglione L (eds) The right to adequate food and access to justice. Bruylant, Brussels, p 117-149

Ize-Charrin MF (2008) Keynote address. In: Debate 'This House believes that climate change violates the universal right of all peoples to live in a safe and sustainable environment', September 17, 2008. UN, Geneva

Lador Y (2004) The challenges of human environmental rights. In: Human rights and the environment. Proceedings of a Geneva Environment Network Roundtable. UNEP, Geneva, p 7- 13

Loucaides L (2004) Environmental protection through the jurisprudence of the ECHR. BYBIL. Oxford University Press, Oxford, p 249-267

MacDonald KE (2008) A right to a healthy environment. Humans and habitats: rethinking rights in an age of climate change. In: European Energy and Environmental Law Review. Kluwer Law International, Alphen, p 213-226
McMichael AJ, Woodruff RE (2006) Climate change and human health: present and future risks. The Lancet 367 : 859-869

Merino M (2006) Protection de l'individu contre les nuisances environnementales: de la jurisprudence de la Cour européenne des droits de l'homme au système jurisdictionnel national de protection. Rev trim $\mathrm{dr} h$ 65:55-86

Pallemaerts M (2004) Proceduralizing environmental rights: the Aarhus Convention on access to information, public participation in decision-making and access to justice in environmental matters in a human rights context. In: Human rights and the environment. Proceedings of a Geneva Environment Network Roundtable. UNEP, Geneva, p 14-22

Patz JA, Epstein PR, Burke TA, Balbus JM (1996) Global climate change and emerging infection diseases. JAMA 275:217-223

Perrez FX (2004) Key questions concerning the human rights and environment debate. An introduction. In: Human rights and the environment. Proceedings of a Geneva Environment Network Roundtable. UNEP, Geneva, p 4-6

Picolotti R (2008) Foreword. In: Climate change and human rights. A rough guide. International Council on Human Rights Policy, Geneva

Riedel E (2005) The right to water. In: Dicke K et al. (eds) Liber amicorum Jost Delbrück. Dunkers and Humboldt, Berlin, p 585-606

Riedel E (2006) The right to water and general comment No. 15 of the CESCR. In: Rothen P, Riedel E (eds) The right to water. Berliner Wissenschaftsverlag, Berlin, p 19-36

Riedel E (2010) The right to life and the right to health, in particular the obligation to reduce child mortality. In: Tomuschat C (ed) The right to life. Martinus Nijhoff, Leiden, p 351-369

Robinson M (2008) Foreword. In: Climate change and human rights. A rough guide. International Council on Human Rights Policy, Geneva

Sands P (2004) Human rights and the environment. In: UNEP (ed) Human rights and the environment. Proceedings of a Geneva Environment Network Roundtable. UNEP, Geneva, p 22-28

Sanz-Caballero S (2006) La familia en perspectiva internacional y europea. Tirant, Valencia

Sheffield PE, Landrigan PE (2011) Global climate change and children's health: threats and strategies for prevention. Environ Health Perspect 119:291-298

Toeves A (1999) The right to health as a human right. Intersectia, Antwerpen

Veneman AM (2007) Foreword. In: Climate change and children. UNICEF, New York, NY

Wagle NP (2008) Editorial: effects of climate change on specific human rights. In: The rising Nepal. Available at: www.gorkhatapra.org.np

Walden D, Hall N, Hawrylyshyn K (2009) Global warning: children's right to be heard in global climate change negotiations. PLAN, London

Ziegler J (2003) Le droit à l'alimentation. Editions Mille et une nuits, Paris

Ziegler J (2005) L'empire de la honte. Fayard, Paris

Ziegler J (2008) La haine d'Occident. Albin Michel, Paris 